\title{
Ventilation strategies with different inhaled Oxygen conceNTration during CardioPulmonary Bypass in cardiac surgery (VONTCPB): study protocol for a randomized controlled trial
}

\author{
Meng-Qiu Zhang ${ }^{1}$, Yu-Qi Liao ${ }^{1}$, Hong Yu' ${ }^{1}$, Xue-Fei Li ${ }^{1}$, Liang Feng ${ }^{1}$, Xiao-Yun Yang ${ }^{2^{*}}$ and Hai Yu ${ }^{1 *}$
}

\begin{abstract}
Background: There is no consensus on the ventilation management during cardiopulmonary bypass (CPB), and the anesthesiologists or the surgeons usually ventilate the lungs with different ventilation strategies or keep them static. Better outcomes are more likely to occur when the ventilation is administered during CPB according to the existing literatures. However, the use of high fraction of inspired oxygen $\left(\mathrm{FiO}_{2}\right)$ is debatable in cardiac surgery. And the potential effects of strategies combining low tidal volume $\left(\mathrm{V}_{\mathrm{T}}\right)$ ventilation with different $\mathrm{FiO}_{2}$ during $\mathrm{CPB}$ on postoperative pulmonary complications (PPCS) are unclear.

Design: The VONTCPB trial is a single-center, prospective, double-blinded, randomized, controlled trial. We are going to recruit total 420 elective cardiac surgery patients with median sternotomy under CPB, who will be equally randomized into three different ventilation strategy groups: NoV, LOV and HOV. (1) The NoV group receives no mechanical ventilation during CPB; (2) the LOV group receives a low $V_{T}$ of $3-4 \mathrm{ml} / \mathrm{kg}$ of ideal body weight (IBW) with the respiratory rate (RR) of 10-12 acts/min, and the positive end-expiratory pressure (PEEP) of $5-8 \mathrm{cmH}_{2} \mathrm{O}$ during $\mathrm{CPB}$; the $\mathrm{FiO}_{2}$ is 30\%; (3) the HOV group receives a low $V_{T}$ of $3-4 \mathrm{ml} / \mathrm{kg}$ of IBW with the RR of 10-12 acts/min, and the PEEP of 5-8 $\mathrm{cmH}_{2} \mathrm{O}$ during CPB; the $\mathrm{FiO}_{2}$ is $80 \%$. The primary endpoints are the incidence of the composite of PPCs and the PPCs score. The secondary endpoints refer to the incidence of the oxygenation index $\left(\mathrm{PaO}_{2} / \mathrm{FiO}_{2}\right.$ ratio $)<300 \mathrm{mmHg}$ at three time points (the moment arriving in the ICU, 6 and $12 \mathrm{~h}$ after arrival in the ICU), the surgical incision healing grade, the intubation time, the stay of ICU, the length of hospital stay, and mortality at 30 days after the surgery.
\end{abstract}

Discussion: The VONTCPB trial is the first study to assess the effects of strategies combining low tidal volume $\left(V_{T}\right)$ ventilation with different $\mathrm{FiO}_{2}$ during $\mathrm{CPB}$ on patients' outcomes.

Trial registration: ChiCTR1800015261. Registered on 20 March 2018.

Keywords: Cardiopulmonary bypass, Low tidal volume, Mechanical ventilation, Oxygen concentration, Postoperative pulmonary complications

\footnotetext{
*Correspondence: cdyangxiaoyun@163.com; yuhaishan117@yahoo.com ${ }^{2}$ Department of Obstetrics and Gynecology, West China Second University Hospital, Sichuan University, Chengdu, China

${ }^{1}$ Department of Anesthesiology, West China Hospital, Sichuan University, Chengdu 610041, China
}

(c) The Author(s). 2019 Open Access This article is distributed under the terms of the Creative Commons Attribution 4.0 International License (http://creativecommons.org/licenses/by/4.0/), which permits unrestricted use, distribution, and reproduction in any medium, provided you give appropriate credit to the original author(s) and the source, provide a link to the Creative Commons license, and indicate if changes were made. The Creative Commons Public Domain Dedication waiver (http://creativecommons.org/publicdomain/zero/1.0/) applies to the data made available in this article, unless otherwise stated. 


\section{Background}

Surgical and anesthesia techniques of heart surgery have been greatly improving. However, the postoperative pulmonary complications (PPCs) are still the main complications after surgery, resulting in increasing mortality in cardiac surgery with the incidence of 25\% [1]. The PPCs have the forms of respiratory failure, respiratory infection, pleural effusion resulting in thoracentesis, atelectasis, pneumothorax, bronchospasm, aspiration pneumonitis [2]. These complications extend the length of mechanical ventilation and intensive care unit (ICU) stay, indicating worse prognosis $[3,4]$.

The etiologies of the PPCs are quite complicated. Lungs are isolated from the artificial extracorporeal circulation, which results in blood supply to the lungs only from the bronchial arteries. While two sets of independent circulation systems composing the blood delivery system of the lungs, the bronchial arteries supply only about $3-5 \%$ of the pulmonary blood flow system, which may be reduced to one-tenth of the original upon experimental conditions of $\mathrm{CPB}$ in pigs model. Those reduced blood flow may be difficult to meet the physiological metabolic needs of the lungs [5]. The tissue of the lungs is also very loose, vascular fluid can be easily transferred to the interstitial tissue under pathologic conditions. Those factors, in addition to the strikes of pulmonary ischemia-reperfusion and reoxygenation, oxygen-free radicals, inflammatory response make the lungs especially vulnerable in the dedicated phases [4].

Perioperative hyperoxia has been declared to bring some benefits. As is known to us all, the increase in the arterial blood partial pressure of oxygen $\left(\mathrm{PaO}_{2}\right)$ could compensate the adverse effects of a reduction in cardiac output on tissue oxygenation. In addition, $80 \%$ fraction of inspired oxygen $\left(\mathrm{FiO}_{2}\right)$, hyperoxia can increase the activity of antioxidative enzymes and reduce the oxidative stress induced by ischemia and reperfusion acting similarly to the effect of ischemic preconditioning, thus exerts an active therapeutic effect on organ ischemia-reperfusion injury [6, 7]. However, studies have suggested that hyperoxia associated lung injury and its possible mechanisms [8]. A review suggested that the best usage of hyperoxia is in the timing [9]. Anyway, the debate is still on going.

The common practice of respiratory management during $\mathrm{CPB}$ is to suspend the ventilation [10]. Re-expansion pulmonary edema occurs during a long-period collapsed pulmonary reopening, resulting in the reduced lung compliance and ventilation perfusion ratio imbalance [11]. Continuous ventilation during $\mathrm{CPB}$ may somehow reduce the pulmonary edema and inflammation. However, the setting of the ventilation parameters is the work of art. A lot of randomized controlled trials (RCTs) were designed to investigate the influence of different ventilation strategies during $\mathrm{CPB}$ on the outcomes in heart surgery patients [12-27]. All these RCTs have their own limits. Though the evidence is weak, it still suggests that maintaining mechanical ventilation during $\mathrm{CPB}$ is beneficial to lung protection.

The recent meta-analysis made by our research team shows that the ventilation of the resting lung during $\mathrm{CPB}$ is indeed effective in improving the oxygenation $\left(\mathrm{PaO}_{2} / \mathrm{FiO}_{2}\right.$ ratio $)$ and gas exchange. This approach can also reduce the alveolar-arterial oxygen partial pressure difference and the intrapulmonary shunt. But it is unclear of its effect on the long-term prognosis and outcomes for patients. The authors pointed that different $\mathrm{FiO}_{2}$ and other respiratory parameters settings may impact the long-term outcomes [28]. An earlier meta-analysis summarized the publications of different ventilation strategies during $\mathrm{CPB}$. Using continuous positive airway pressure (CPAP) and lung recruitment maneuvers can increase oxygenation immediately after $\mathrm{CPB}$ to a certain extent, but there is no evidence of a sustained effect [29]. A just published systematic review and meta-analysis concluded that CPAP during $\mathrm{CPB}$ may improve the oxygenation and gas exchange while ventilation did not. The authors mentioned that the $\mathrm{FiO}_{2}$ had been ignored for a long period [30]. Heinrichs et al. [31] reviewed the RCTs to investigate the impact that hyperoxia has on postoperative organ dysfunction, length of stay, and mortality during adult cardiac surgery. They concluded that the impact of hyperoxia on these outcomes seems to be minimal because of the high heterogeneity of include studies. Similarly, McGuinness et al. [32] failed to demonstrate any difference in AKI, markers of organ damage, or length of stay by comparing the avoidance of arterial hyperoxemia versus usual care during $\mathrm{CPB}$.

There is no generally accepted ventilation management model due to weak evidence of heterogeneity researches $[10,33,34]$. Therefore, we designed a prospective RCT combining the different regimens of ventilation settings during $\mathrm{CPB}$ with low or high $\mathrm{FiO}_{2}$ to explore the optimal ventilation mode during $\mathrm{CPB}$.

\section{Objectives}

We designed this RCT to compare the clinical effects of three mechanical ventilation strategies on the total incidence of PPCs during postoperative hospitalization. We chose the incidence of composite PPCs as the primary outcome because it is a hard parameter. While in the past many studies only focused on observing biochemical indicators or indirect parameters. You could never tell whether those indicators in the blood have sustained influences in the long run or not. It could be just a transient change after surgery. We hope we would reach a conclusion of optimal ventilation management during $\mathrm{CPB}$, and finally we could make a difference in the clinical practice. 


\section{Methods/design}

The VONTCPB study is a single-center, double-blinded, three-armed, randomized controlled trial comparing three mechanical ventilation strategies (NoV, LOV and $\mathrm{HOV}$ ) during $\mathrm{CPB}$ in adult patients undergoing cardiac surgery. The protocol structure is written according to the Consolidated Standards of Reporting Trials (CONSORT) 2010 Statement guidelines and follows the Standard Protocol Items: Recommendations for Interventional Trials (SPIRIT) Statement. The SPIRIT checklist can be found in Additional file 1. The SPIRIT figure is illustrated in Fig. 1.

\section{Ethical approval and trial registration}

This clinical study protocol has been approved by the Biomedical Research Ethics Committee of West China Hospital of Sichuan University on 12 March 2018 (Approval number 2017 (400)) and registered in the
Chinese Clinical Trials Registry (ChiCTR) (www.chictr. org.cn) with the registration number ChiCTR1800015261 on 19 March 2018.

\section{Participants}

The patients included in the trial must be more than 18 years old and undergo elective cardiac surgery with median sternotomy under CPB. Simultaneous other non-cardiac surgery procedure is excluded. The inclusion and exclusion criteria are shown in Table 1.

\section{Endpoints}

The primary endpoints are the incidence of a composite of PPCs and the PPCs score during hospital stay [35-37]. The detailed definitions of PPCs are shown in Table 2. The score is presented in Table 3. Secondary endpoints are listed as follows: the incidence of oxygen index $<300 \mathrm{mmHg}$ at three

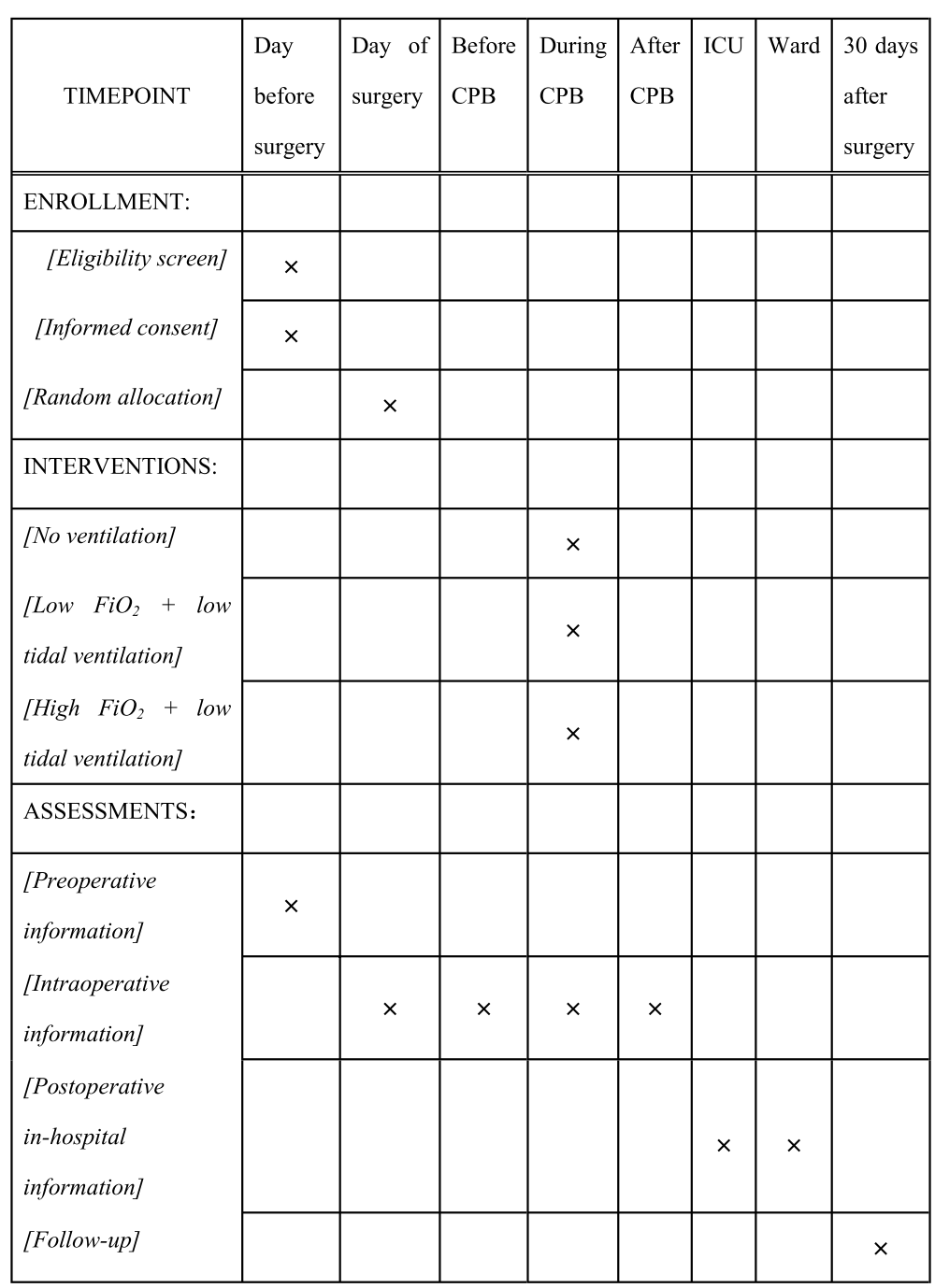

Fig. 1 Flow diagram of allocation, intervention, data collection and follow-up 
Table 1 Eligibility criteria

\begin{tabular}{ll}
\hline Inclusion criteria & Exclusion criteria \\
\hline - Age $\geq 18$ years & - Pregnant women \\
- Signed informed consent & - Heart transplantation, \\
- Elective cardiac surgery & - Pulmonary thromboendarterectomy \\
patients with median & - Aortic arch and other deep \\
sternotomy under CPB. & hypothermic circulatory arrest surgery \\
& - Long-term use of hormone therapy \\
& before surgery ( $\geq 3$ months) \\
& - Participated in other similar researches \\
& 3 months ago \\
\hline
\end{tabular}

time points (the moment arriving in the ICU, 6 and $12 \mathrm{~h}$ after arrival in the ICU), the surgical incision healing grade, the intubation time, the length of ICU stay and hospital stay, and postoperative 30-day mortality rate.

\section{Randomization/Blinding}

The random number table was generated by Microsoft Excel in a 1:1:1 treatment ratio. The investigator who is responsible for grouping visits the patients the day before surgery and gets the consents. Once the patient is qualified, he determines the serial number and random number of the patient and writes on the Case Report Form (CRF). He will also inform the anesthesia care providers who do not participate in the study the treatment of the patient. The patient, the data collector and the intensivist are not aware of the treatment information in the whole process. Any intraoperative event (such as pleura incision) or deviation from the protocol is recorded on the CRF.

\section{Intervention}

The participants will be randomly divided into the following three groups (Fig. 2):

1) The NoV arm: no ventilation during CPB.

2) The LOV arm: participants will receive a low $V_{T}$ of $3-4 \mathrm{ml} / \mathrm{kg}$ of IBW with the RR of $10-12$ acts/min, and the PEEP of $5-8 \mathrm{cmH}_{2} \mathrm{O}$ during $\mathrm{CPB}$; the $\mathrm{FiO}_{2}$ is $30 \%$ with a flow of $2 \mathrm{~L} / \mathrm{min}$.

3) The HOV arm: participants will receive a low $V_{T}$ of $3-4 \mathrm{ml} / \mathrm{kg}$ of IBW with the RR of $10-12$ acts $/ \mathrm{min}$, and the PEEP of $5-8 \mathrm{cmH}_{2} \mathrm{O}$ during $\mathrm{CPB}$; the $\mathrm{FiO}_{2}$ is $80 \%$ with a flow of $2 \mathrm{~L} / \mathrm{min}$.

$\mathrm{FiO}_{2} \quad 80 \%$ will be applied during oxygenation for denitrogenation $5 \mathrm{~min}$ before endotracheal intubation. The lung protective ventilation strategy [34, 37-39] will be applied in the participants before and after CPB: $V_{T}$ $=6-8 \mathrm{ml} / \mathrm{kg}$ IBW, PEEP $=5-8 \mathrm{cmH}_{2} \mathrm{O}$, inspiration/expiration time $\operatorname{ratio}(\mathrm{I}: \mathrm{E})=1: 2, \mathrm{RR}=10-12$ to maintain end-tidal carbon dioxide partial pressure $\left(\mathrm{P}_{\mathrm{ET}} \mathrm{CO}_{2}\right)$

Table 2 Definitions of post-operative pulmonary complications*

\begin{tabular}{|c|c|}
\hline Complication & Definition \\
\hline Respiratory failure & $\begin{array}{l}\text { At least one of the following criteria after surgery: } \\
\text { - } \mathrm{SpO}_{2}<90 \% \text { and requiring oxygen therapy } \\
\text { - } \mathrm{PaO}_{2} / \mathrm{FiO}_{2}<300 \\
\text { - } \mathrm{PaO}_{2}<60 \mathrm{mmHg}\end{array}$ \\
\hline Respiratory infection & $\begin{array}{l}\text { Postoperative antibiotic therapy administered for suspected respiratory } \\
\text { infection with at least one of the following criteria: } \\
\text { - New or changed sputum } \\
\text { - New or changed lung opacity on x-ray } \\
\text { - Fever } \\
\text { - Leukocyte count }>12,000 / \mathrm{mL}\end{array}$ \\
\hline Pleural effusion & $\begin{array}{l}\text { Evidence at chest x-ray of: } \\
\text { - Blunting of the costophrenic sinus } \\
\text { - In upright position: loss of the sharp silhouette of the ipsilateral } \\
\text { hemidiaphragm } \\
\text { - In supine position: hazy opacity in } 1 \text { hemithorax with preserved } \\
\text { vascular shadows } \\
\text { - Displacement of adjacent anatomic structures }\end{array}$ \\
\hline Atelectasis & $\begin{array}{l}\text { Evidence at chest x-ray of: } \\
\text { - New parenchymal opacification } \\
\text { - Shift of the median structures (mediastinum, hilum or hemidiaphragm) } \\
\text { toward the affected area } \\
\text { - Compensatory overinflation of contralateral lung }\end{array}$ \\
\hline Aspiration pneumonitis & $\begin{array}{l}\text { Inhalation of gastric content in the perioperative period with subsequent } \\
\text { acute lung injury }\end{array}$ \\
\hline Broncho spasm & New expiratory wheezing responsive to treatment with bronchodilators \\
\hline Pneumothorax & $\begin{array}{l}\text { At chest x-ray, presence of air within pleural space, with no vascular bed } \\
\text { surrounding the visceral pleura }\end{array}$ \\
\hline
\end{tabular}


Table 3 Postoperative pulmonary complications score

\begin{tabular}{|c|c|}
\hline Grade & Definition \\
\hline $\begin{array}{l}\text { Grade } \\
1\end{array}$ & $\begin{array}{l}\text { - Cough, dry } \\
\text { - Microatelectasis: abnormal lung findings and temperature } \\
>37.5^{\circ} \mathrm{C} \text { without other documented cause; normal chest } \\
\text { radiograph } \\
\text { - Dyspnea, not due to other documented cause }\end{array}$ \\
\hline $\begin{array}{l}\text { Grade } \\
2\end{array}$ & $\begin{array}{l}\text { - Cough, productive, not due to other documented cause } \\
\text { - Bronchospasm: new wheezing or pre-existent wheezing } \\
\text { resulting in a change in therapy } \\
\text { - Hypoxemia ( } \mathrm{SpO}_{2} \leq 90 \% \text { ) at room air } \\
\text { - Atelectasis: gross radiological confirmation (concordance } \\
\text { of } 2 \text { independent experts) plus either temperature }>37.5^{\circ} \mathrm{C} \\
\text { or abnormal lung findings } \\
\text { - Hypercarbia ( } \mathrm{PaCO}_{2}>50 \mathrm{mmHg} \text { ), requiring treatment }\end{array}$ \\
\hline $\begin{array}{l}\text { Grade } \\
3\end{array}$ & $\begin{array}{l}\text { - Pleural effusion, resulting in thoracentesis } \\
\text { - Pneumonia: radiological evidence (concordance of } 2 \\
\text { independent experts) plus clinical symptoms (two of the } \\
\text { following: leucocytosis or leucopenia, abnormal temperature, } \\
\text { purulent secretions), plus either a pathological organism } \\
\text { (by Gram stain or culture), or a required change in antibiotics } \\
\text { - Pneumothorax } \\
\text { - Noninvasive ventilation, strictly applied to those with all of } \\
\text { the following: a) oxygen saturation }\left(\mathrm{SpO}_{2} \text { ) lower than } 92 \%\right. \\
\text { under supplemental oxygen; b) need of supplemental } \\
\text { oxygen }>5 \mathrm{~L} / \mathrm{min} \text {; and } \mathrm{RR} \geq 30 \mathrm{bpm} \\
\text { - Re-intubation postoperative or intubation, period of ventilator } \\
\text { dependence (non-invasive or invasive ventilation) } \leq 48 \mathrm{~h}\end{array}$ \\
\hline $\begin{array}{l}\text { Grade } \\
4\end{array}$ & $\begin{array}{l}\text { - Ventilatory failure: postoperative ventilator dependence } \\
\text { exceeding } 48 \mathrm{~h} \text {, or reintubation with subsequent period of } \\
\text { ventilator dependence exceeding } 48 \mathrm{~h}\end{array}$ \\
\hline $\begin{array}{l}\text { Grade } \\
5\end{array}$ & - Death before hospital discharge \\
\hline
\end{tabular}

between 35 and $45 \mathrm{mmHg}$, and the $\mathrm{FiO}_{2}$ is set to $50 \%$, maintaining pulse oxygen saturation $\left(\mathrm{SpO}_{2}\right) \geq 95 \%$, with a flow of $2 \mathrm{~L} / \mathrm{min}$. If the $\mathrm{SpO}_{2}$ cannot be maintained, the anesthesiologists firstly improve patient oxygenation by changing ventilation parameters and ventilation strategies, such as the application of lung alveolar recruitment maneuver (ARM), and then consider increasing the $\mathrm{FiO}_{2}$. ARM is performed in all participants at the end of $\mathrm{CPB}$, with manual ventilation creating the airway pressure at $30 \mathrm{cmH}_{2} \mathrm{O}$ for at least $5 \mathrm{~s}$. Vasoactive drugs will necessarily be medicated if the hemodynamics is affected by the ARM. Maintaining mixed venous oxygen saturation $\left(\mathrm{SvO}_{2}\right) \geq 60 \%$ during the CPB (70\%-80\% would be preferred).

The synchronized intermittent mandatory ventilation (SIMV) mode will be applied once the participants transferred to the ICU. The ventilator parameters settings are as follow: $\mathrm{V}_{\mathrm{T}}=6-8 \mathrm{ml} / \mathrm{kg}$ of $\mathrm{IBW}, \mathrm{PEEP}=8 \mathrm{cmH}_{2} \mathrm{O}$, I: $\mathrm{E}=1: 2, \mathrm{FiO}_{2}=50 \% . \mathrm{FiO}_{2}$ is adjusted according to the $\mathrm{PaO}_{2}$ by performing arterial blood gas (ABG) analyses: if $\mathrm{PaO}_{2} \geq 150 \mathrm{mmHg}$, it is decreased by $10 \%$; but if $\mathrm{PaO}_{2} \leq 80 \mathrm{mmHg}$, then it is increased by $10 \%$; minimum $\mathrm{FiO}_{2}$ is $30 \%$. Any additional ARM will be recorded. Other therapeutic approaches and decisions are up to the ICU physicians.

\section{Perioperative management and monitoring}

All these participants will be managed and monitored following the general standard of the practices of the Department of Anesthesiology, West China Hospital of Sichuan University no matter which group they belong to. Intraoperative standard monitoring includes capnography, electrocardiogram (ECG), pulse oximeter, invasive arterial blood pressure, central venous pressure, urine output, nasopharyngeal temperature, transesophageal echocardiogram (TEE), activated clotting time (ACT). Other managements are optional, including bispectral index (BIS) and cerebral oxygen saturation monitoring.

The anesthesiologists give the participants heparin $(3 \mathrm{mg} / \mathrm{kg}$ ) to obtain an ACT of $280 \mathrm{~s}$ for aortic cannulation and $480 \mathrm{~s}$ before starting the $\mathrm{CPB}$. At the end of the $\mathrm{CPB}$, protamine is given to antagonize heparin with 1:1. The target ACT is about the same as the baseline value. Mean arterial pressure will be kept between 50 and $70 \mathrm{mmHg}$ during CPB.

\section{Data collection}

All the related data are collected on the CRF. Preoperative data include age, height, weight, EuroSCORE II, smoking status, diabetes mellitus, peripheral arterial disease, pulmonary comorbidity, pulmonary infection in the past 30 days and the classification of American Society of Anesthesiologists (ASA). Intraoperative data include type and duration of surgery procedure, duration of $\mathrm{CPB}$ and aortic cross clamp, units of allogeneic red blood cell transfusions, volume and type of fluids administered. Postoperative data include time to extubation, need for non-invasive ventilator, re-intubation, postoperative hospital stay, temperature, leukocyte count and chest X-ray. Other data at three time points (the moment arriving in the ICU, 6 and $12 \mathrm{~h}$ after arrival in the ICU) include $\mathrm{PaO}_{2}$, $\mathrm{FiO}_{2}$, and partial pressure of carbon dioxide $\left(\mathrm{PaCO}_{2}\right)$. PPCs events are traced throughout the hospitalization.

\section{Statistical considerations Sample size}

Sample-size calculation is based on two-sided alpha error of 0.05 and $80 \%$ power. We performed a pilot-study, showing that the $\mathrm{P}_{\max }$ is $40 \%$ in the LOV group (15 patients) and the $\mathrm{P}_{\min }$ is $22 \%$ in the NoV group (14 patients). Therefore, we expect a reduction of $45 \%$ in the incidence of this parameter, and then calculate the sample size of 127 patients per group (381 in total). Considering a dropout fraction of $10 \%$, we will finally need a total of 420 participants.

\section{Data analysis}

Data will be analyzed following the intention-to-treat principle using SPSS version 22.0 (SPSS, Chicago, IL, USA). Comparisons in the dichotomous variables will be 


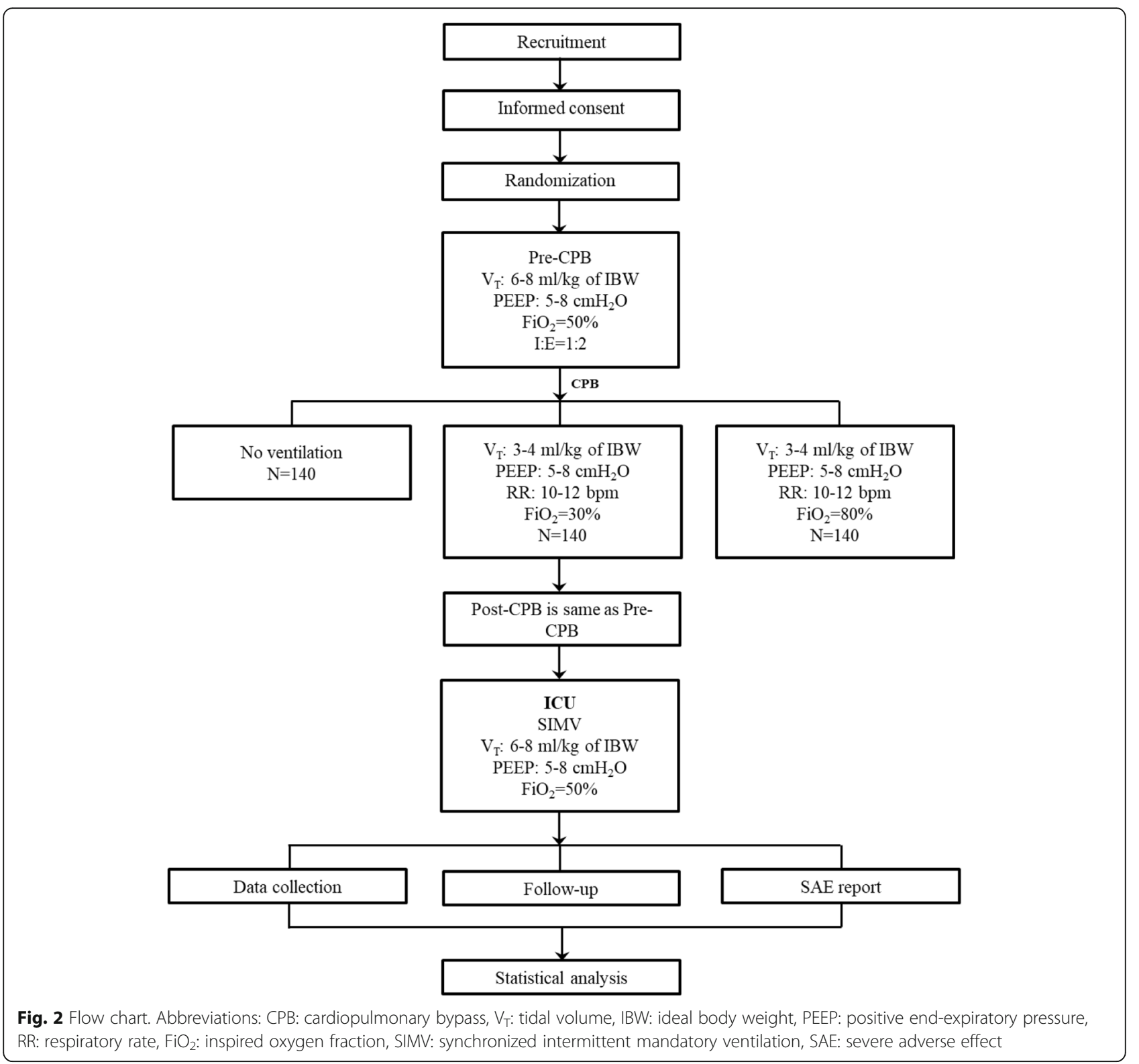

made by the chi-square tests (or Fisher exact tests where numbers are small). Comparisons in the continuous variables will be made by analysis of variance or the nonparametric Kruskal-Wallis $\mathrm{H}$ test. Two-sided significance tests will be used throughout. The Results will be presented as $\mathrm{n}(\%)$, mean (SD), or median (interquartile range). Bonferroni correction will be used when doing post hoc analysis.

\section{Discussion}

About 1-1.25 million patients undergo cardiac surgery worldwide each year and the number continues to increase [40]. CPB is an essential part of major cardiac surgery which may induce PPCs after operation. Since the PPCs are leading causes of mortality and morbidity [37], the effective preventive measures are particularly important and urgently needed. Various researches have been performed to reach this goal. The MECANO trial (NCT03098524) aims to assess the effects of mechanical ventilation $\left(\mathrm{V}_{\mathrm{T}}: 3 \mathrm{ml} / \mathrm{kg}\right.$, PEEP: $5 \mathrm{cmH}_{2} \mathrm{O}$, RR: $\left.5 \mathrm{bpm}\right)$ on all-cause mortality and respiratory failure comparing with no ventilation during $\mathrm{CPB}$ [41]. It does not provide the detailed usage of oxygen though the ambitious number of patients $(n=1500)$. The CPBVENT trial (NCT02090205) is a three-armed multicenter study [42], which compares two different ventilation strategies (CPAP: $5 \mathrm{cmH}_{2} \mathrm{O}$ or $\mathrm{V}_{\mathrm{T}}: 2-3 \mathrm{ml} / \mathrm{kg}$ of IBW, PEEP: 3-5 $\mathrm{cmH}_{2} \mathrm{O}, \mathrm{RR}: 5 \mathrm{bpm}$ ) with no ventilation during CPB. This trial's primary endpoint $\left(\mathrm{PaO}_{2} / \mathrm{FiO}_{2}\right.$ ratio $)$ can be easily identified, observed, and calculated, but indirect. 
That is why we use it as a secondary endpoint. Besides, the inclusion and exclusion criteria are relatively strict, making the conclusion only applicable to a specific group of populations. The purpose of the VONTCPB study is to determine the impact that the different $\mathrm{FiO}_{2}$ has on the PPCs when combining the ventilation strategy with low $\mathrm{V}_{\mathrm{T}}(3-4 \mathrm{ml} / \mathrm{kg}$ of IBW, only about half of the normal tidal volume), routine respiratory rate (10-12 bpm) and PEEP $\left(5-8 \mathrm{cmH}_{2} \mathrm{O}\right)$ during CPB. This trial is the first study to investigate the effect of oxygen under different ventilation strategy during $\mathrm{CPB}$. The number of the sample size $(n=420)$ is adequate. The primary endpoints are clinically relevant. The purpose of setting ventilator parameters in this way is to make the ventilation closer to the general. And this ventilation management during $\mathrm{CPB}$ may potentially benefit patients' outcomes, but at the same time it has an imperceptible impact on the operating field.

There are limitations of the trial due to the inherent properties such as its single-center design. It is questionable whether the conclusion drawn by the VONTCPB trial can be applied in other hospitals because of the different clinical practice in other hospitals. Besides, only the volume controlled ventilation mode is applied, so it is unknown whether it is also applicable in other ventilation mode, such as pressure controlled mode.

In general, the VONTCPB trial would answer the question that whether maintaining mechanical ventilation during $\mathrm{CPB}$ is more preferable than no ventilation. Better still, which level of $\mathrm{FiO}_{2}$ is beneficial to patients will be determined from this trial.

\section{Trial status}

The trial was started after we obtained the approval of local ethics committee and registered in the Chinese Clinical Trials Registry. We plan to spend six months to include cases and complete the trial in November 2018.

\section{Additional file}

Additional file 1: The SPIRIT 2013 checklist of this trial. (DOCX $53 \mathrm{~kb}$ )

\footnotetext{
Abbreviations

ABG: Arterial blood gas; ACT: Activated clotting time; ARM: Alveolar recruitment maneuver; ASA: American Society of Anesthesiologists; BIS: Bispectral index; CPAP: Continuous positive airway pressure; CPB: Cardiopulmonary bypass; CRF: Case report form;

ECG: Electrocardiogram; $\mathrm{FiO}_{2}$ : Inhaled oxygen concentration; IBW: Ideal body weight; ICU: Intensive care unit; $\mathrm{PaCO}_{2}$ : Partial pressure of carbon dioxide: $\mathrm{PaO}_{2}$ : Arterial blood partial pressure of oxygen; PEEP: Positive end-expiratory pressure; $\mathrm{P}_{\mathrm{ET}} \mathrm{CO}_{2}$ : End-tidal carbon dioxide partial pressure;

PPCs: Postoperative pulmonary complications; RCTs: Randomized controlled trials; RR: Respiratory rate; SIMV: Synchronized intermittent mandatory ventilation; $\mathrm{SpO}_{2}$ : Pulse oxygen saturation; $\mathrm{SvO}_{2}$ : Mixed venous oxygen saturation; TEE: Transesophageal echocardiogram; $V_{T}$ : Tidal volume
}

Acknowledgements

Not applicable.

Funding

Not applicable.

Availability of data and materials

Not applicable.

\section{Authors' contributions}

$X Y Y$ and $H Y$ provided the original idea of this randomized controlled trial. $H Y$ and MQZ contributed to the study concept and design and wrote the manuscript. YQL and LF participated patients' recruitment and data collection. XFL contributed to the sample size design and data analysis. All authors read and approved the final manuscript.

\section{Authors' information}

See the title page.

\section{Ethics approval and consent to participate}

This clinical study protocol has been approved by the West China Hospital of Sichuan University Biomedical Research Ethics Committee on 12 March 2018 (Approval number 2017 (400)). We will obtain informed consent from patients when recruiting before the experiment. The patients can withdraw from the trial at any time.

\section{Consent for publication}

All authors agree to its submission to Trials and publish it.

\section{Competing interests}

The authors declare that they have no competing interests.

\section{Publisher's Note}

Springer Nature remains neutral with regard to jurisdictional claims in published maps and institutional affiliations.

Received: 11 September 2018 Accepted: 28 March 2019

Published online: 03 May 2019

\section{References}

1. Apostolakis E, Filos KS, Koletsis E, Dougenis D. Lung dysfunction following cardiopulmonary bypass. J Card Surg. 2010;25:47-55.

2. Bignami E, Guarnieri M, Saglietti F, Belletti A, Trumello C, Giambuzzi I, et al. Mechanical Ventilation During Cardiopulmonary Bypass. J Cardiothorac Vasc Anesth. 2016;30(6):1668-75.

3. Lellouche F, Lipes J. Prophylactic protective ventilation: lower tidal volumes for all critically ill patients? Intensive Care Med. 2013;39:6-15.

4. Huffmyer JL, Groves DS. Pulmonary complications of cardiopulmonary bypass. Best Pract Res Clin Anaesthesiol. 2015;29:163-75.

5. Schlensak C, Doenst T, Preusser S, Wunderlich M, Kleinschmidt M, Beyersdorf F. Cardiopulmonary bypass reduction of bronchial blood flow: a potential mechanism for lung injury in a neonatal pig model. J Thorac Cardiovasc Surg. 2002;123:1199-205.

6. Brown DM, Holt DW, Edwards JT, Burnett RJ 3rd. Normoxia vs hyperoxia: impact of oxygen tension strategies on outcomes for patients receiving cardiopulmonary bypass for routine cardiac surgical repair. J Extra Corpor Technol. 2006;38:241-8.

7. Mariero LH, Rutkovskiy A, Stenslokken KO, Vaage J. Hyperoxia during early reperfusion does not increase ischemia/reperfusion injury. Eur 」 Cardiothorac Surg. 2012;41:149-53.

8. Kallet RH, Matthay MA. Hyperoxic acute lung injury. Respir Care. 2013;58:123-41.

9. Young RW. Hyperoxia: a review of the risks and benefits in adult cardiac surgery. J Extra Corpor Technol. 2012;44:241-9.

10. Fischer MO, Courteille B, Guinot PG, Dupont H, Gerard JL, Hanouz JL, et al. Perioperative Ventilatory Management in Cardiac Surgery: A French Nationwide Survey. Medicine (Baltimore). 2016;95:e2655.

11. Sohara Y. Reexpansion pulmonary edema. Ann Thorac Cardiovasc Surg. 2008:14:205-9.

12. Vohra HA, Levine A, Dunning J. Can ventilation while on cardiopulmonary bypass improve post-operative lung function for patients undergoing cardiac surgery? Interact Cardiovasc Thorac Surg. 2005;4:442-6. 
13. Beer $L$, Szerafin T, Mitterbauer A, Debreceni T, Maros T, Dworschak M, et al. Low tidal volume ventilation during cardiopulmonary bypass reduces postoperative chemokine serum concentrations. Thorac Cardiovasc Surg. 2014;62:677-82.

14. Durukan AB, Gurbuz HA, Salman N, Unal EU, Ucar HI, Yorgancioglu CE. Ventilation during cardiopulmonary bypass did not attenuate inflammatory response or affect postoperative outcomes. Cardiovasc J Afr. 2013;24:224-30.

15. Beer L, Szerafin T, Mitterbauer A, Kasiri MM, Debreceni TPL, Dworschak M, et al. Ventilation during cardiopulmonary bypass: impact on heat shock protein release. J Cardiovasc Surg. 2014;55:849-56.

16. Beer $L$, Szerafin T, Mitterbauer A, Debreceni T, Maros T, Dworschak M, et al. Continued mechanical ventilation during coronary artery bypass graft operation attenuates the systemic immune response. Eur J Cardiothorac Surg. 2013;44:282-7.

17. Beer L, Warszawska JM, Schenk P, Debreceni T, Dworschak M, Roth GA, et al. Intraoperative ventilation strategy during cardiopulmonary bypass attenuates the release of matrix metalloproteinases and improves oxygenation. J Surg Res. 2015;195:294-302.

18. Gagnon J, Laporta D, Beique F, Langlois Y, Morin JF. Clinical relevance of ventilation during cardiopulmonary bypass in the prevention of postoperative lung dysfunction. Perfusion. 2010;25:205-10.

19. Davoudi M, Farhanchi A, Moradi A, Bakhshaei MH, Safarpour G. The Effect of Low Tidal Volume Ventilation during Cardiopulmonary Bypass on Postoperative Pulmonary Function. J Tehran Heart Cent. 2010;5:128-31.

20. Scherer M, Dettmer S, Meininger D, Deschka H, Geyer G, Regulla C, et al. Alveolar recruitment strategy during cardiopulmonary bypass does not improve postoperative gas exchange and lung function. Cardiovasc Eng. 2009;9:1-5

21. John LC, Ervine IM. A study assessing the potential benefit of continued ventilation during cardiopulmonary bypass. Interact Cardiovasc Thorac Surg. 2008;7:14-7

22. Altmay E, Karaca P, Yurtseven N, Ozkul V, Aksoy T, Ozler A, et al. Continuous positive airway pressure does not improve lung function after cardiac surgery. Can J Anaesth. 2006:53:919-25.

23. Claxton BA, Morgan P, McKeague H, Mulpur A, Berridge J. Alveolar recruitment strategy improves arterial oxygenation after cardiopulmonary bypass. Anaesthesia. 2003;58:111-6.

24. Zabeeda D, Gefen R, Medalion B, Khazin V, Shachner A, Ezri T. The effect of high-frequency ventilation of the lungs on postbypass oxygenation: $A$ comparison with other ventilation methods applied during cardiopulmonary bypass. J Cardiothorac Vasc Anesth. 2003;17:40-4.

25. Figueiredo LC, Araujo S, Abdala RC, Abdala A, Guedes CA. CPAP at $10 \mathrm{~cm}$ $\mathrm{H} 2 \mathrm{O}$ during cardiopulmonary bypass does not improve postoperative gas exchange. Rev Bras Cir Cardiovasc. 2008;23:209-15.

26. Macedo Fl, Gologorsky E, Costa AC, Pham SM, Salerno TA. Beating heart surgery with pulmonary perfusion and ventilation during cardiopulmonary bypass: target organs' perfusion without plegia. Semin Thorac Cardiovasc Surg. 2012;24:308-10.

27. Ayad AE, Hamed HF. Continuous positive airway pressure (CPAP) during cardiopulmonary bypass attenuates postoperative pulmonary dysfunction and complications; 2003. p. 345-51.

28. Chi D, Chen C, Shi Y, Wang W, Ma Y, Zhou R, et al. Ventilation during cardiopulmonary bypass for prevention of respiratory insufficiency: A metaanalysis of randomized controlled trials. Medicine (Baltimore). 2017;96:e6454.

29. Schreiber JU, Lance MD, de Korte M, Artmann T, Aleksic I, Kranke P. The effect of different lung-protective strategies in patients during cardiopulmonary bypass: a meta-analysis and semiquantitative review of randomized trials. J Cardiothorac Vasc Anesth. 2012;26:448-54.

30. Wang YC, Huang CH, Tu YK. Effects of Positive Airway Pressure and Mechanical Ventilation of the Lungs During Cardiopulmonary Bypass on Pulmonary Adverse Events After Cardiac Surgery: A Systematic Review and Meta-Analysis. J Cardiothorac Vasc Anesth. 2018;32:748-59.

31. Heinrichs J, Lodewyks C, Neilson C, Abou-Setta A, Grocott HP. The impact of hyperoxia on outcomes after cardiac surgery: a systematic review and narrative synthesis. Can J Anaesth. 2018;65:923-35.

32. McGuinness SP, Parke RL, Drummond K, Willcox T, Bailey M, Kruger C, et al. A Multicenter, Randomized, Controlled Phase Ilb Trial of Avoidance of Hyperoxemia during Cardiopulmonary Bypass. Anesthesiology. 2016;125:465-73.
33. Ferrando C, Soro M, Belda FJ. Protection strategies during cardiopulmonary bypass: ventilation, anesthetics and oxygen. Curr Opin Anaesthesiol. 2015;28:73-80.

34. Lellouche F, Delorme M, Bussieres J, Ouattara A. Perioperative ventilatory strategies in cardiac surgery. Best Pract Res Clin Anaesthesiol. 2015;29:381-95.

35. Kroenke K, Lawrence VA, Theroux JF, Tuley MR. Operative risk in patients with severe obstructive pulmonary disease. Arch Intern Med. 1992;152:967-71.

36. Hulzebos EH, Helders PJ, Favie NJ, De Bie RA, Brutel de la Riviere A, Van Meeteren NL. Preoperative intensive inspiratory muscle training to prevent postoperative pulmonary complications in high-risk patients undergoing CABG surgery: a randomized clinical trial. JAMA. 2006;296:1851-7.

37. Futier E, Constantin JM, Paugam-Burtz C, Pascal J, Eurin M, Neuschwander A et al. A trial of intraoperative low-tidal-volume ventilation in abdominal surgery. N Engl J Med. 2013;369:428-37.

38. Lellouche F, Dionne S, Simard S, Bussieres J, Dagenais F. High tidal volumes in mechanically ventilated patients increase organ dysfunction after cardiac surgery. Anesthesiology. 2012;116:1072-82.

39. Ladha K, Vidal Melo MF, McLean DJ, Wanderer JP, Grabitz SD, Kurth T, et al. Intraoperative protective mechanical ventilation and risk of postoperative respiratory complications: hospital based registry study. BMJ. 2015;351:h3646.

40. Herbertson M. Recombinant activated factor VII in cardiac surgery. Blood Coagul Fibrinolysis. 2004;15(Suppl 1):S31-2.

41. Nguyen LS, Merzoug M, Estagnasie P, Brusset A, Law Koune JD, Aubert S, et al. Low tidal volume mechanical ventilation against no ventilation during cardiopulmonary bypass heart surgery (MECANO): study protocol for a randomized controlled trial. Trials. 2017;18:582.

42. Bignami E, Guarnieri M, Saglietti F, Maglioni EM, Scolletta S, Romagnoli S, et al. Different strategies for mechanical VENTilation during CardioPulmonary Bypass (CPBVENT 2014): study protocol for a randomized controlled trial. Trials. 2017;18:264.

\section{Ready to submit your research? Choose BMC and benefit from:}

- fast, convenient online submission

- thorough peer review by experienced researchers in your field

- rapid publication on acceptance

- support for research data, including large and complex data types

- gold Open Access which fosters wider collaboration and increased citations

- maximum visibility for your research: over $100 \mathrm{M}$ website views per year

At BMC, research is always in progress.

Learn more biomedcentral.com/submissions 